Esta revista forma parte del acervo de la Biblioteca Jurídica Virtual del Instituto de Investigaciones Jurídicas de la UNAM www.juridicas.unam.mx

www.bibliojuridica.org

PROBLEMA

Anuario de Filosofia

y Teoría del Derecho

\title{
LAW AND REASONS: COMMENTS ON RODRIGUEZ-BLANCO
}

\author{
Brian H. BIX ${ }^{1}$
}

Resumen:

Veronica Rodriguez-Blanco explora con minuciosidad en su detallado e importante artículo, "Reasons in Action $v$ Triggering Reasons: A Reply to Enoch on Reason-Giving and Legal Normativity", la naturaleza del otorgamiento de razones, en aras de cuestionar el influyente trabajo reciente de David Enoch sobre el otorgamiento de razones y el derecho. Si bien el artículo de Rodriguez-Blanco constituye una importante contribución a la literatura en cuanto a la mejor comprensión del otorgamiento de razones y la razón práctica, no está claro si el enfoque hacia las razones para la acción, reformado sobre la línea de lo que sugiere Rodríguez-Blanco, clarificaria la cuestión primordial de la que se ocupa: la manera en que los sistemas jurídicos en general o las normas jurídicas individuales le dan (o no) a los ciudadanos razones para la acción. La cuestión sobre si tenemos una obligación moral (presuntiva) general de actuar (o de abstenerse de actuar) tal como lo disponen las normas depende en gran medida de si hay buenos argumentos en contra de un enfoque individualista y casuístico para responder a tales normas.

\section{Palabras clave:}

Razón práctica, normas y razones, obligación moral de obedecer el derecho, normatividad del derecho.

1 Frederick W. Thomas Professor of Law and Philosophy, University of Minnesota. I am grateful for the comments and suggestions of William A. Edmundson. 
BRIAN H. BIX

\begin{abstract}
:
In Veronica Rodriguez-Blanco's thoughtful and important article, "Reasons in Action $v$ Triggering Reasons: A Reply to Enoch on Reason-Giving and Legal Normativity," she explores with great care the nature of reason-giving, in connection with challenging David Enoch's influential recent work on reason-giving and the law. While Rodriguez-Blanco's article makes an important contribution to the literature on the best understanding of reason-giving and practical reasoning, it is not clear that an approach to reasons for action reformed along the lines Rodriguez-Blanco suggests would change or clarify the ultimate question on which she focuses: the way in which legal systems in general or individual legal norms do (or do not) give citizens reasons for action. The question of whether we have a general (presumptive) moral obligation to act (or refrain from acting) as legal norms direct us depends to a significant degree on whether there are good arguments against an individualistic, case by case, approach to responding to such norms.
\end{abstract}

Keywords:

Practical Reason, Norms and Reasons, Moral Obligation to Obey the Law, Normativity of Law. 
LAW AND REASONS

SUMMARY: Introduction. I. Explaining the Normativity of Law. II. Theory (Theories) of Reasons for Action. III. Law and Reason-Giving. Conclusion.

\section{INTRODUCTION}

In Veronica Rodriguez-Blanco's thoughtful and important article, "Reasons in Action $v$ Triggering Reasons: A Reply to Enoch on Reason-Giving and Legal Normativity",2 she explores with great care the nature of reason-giving, in connection with challenging David Enoch's influential recent work on reason-giving and the law. ${ }^{3}$

In this response, I will focus primarily on the background issue that creates the context for the debate between Rodriguez-Blanco and Enoch: the "problem of normativity" in law, the question of whether, when, and how legal norms create reasons for actions for citizens. In what follows, Part I explores what commentators means when they state that there is a problem regarding "the normativity of law" that needs explanation. After a brief discussion in Part II of some difficulties in theories about reasons for action, Part III considers barriers to the conclusion that legal norms always give us reasons for action.

2 All references to "Reasons in Action $v$ Triggering Reasons" will be given as [manuscript] page numbers in parentheses. References to other works will be in footnotes.

3 David Enoch, "Reason-giving and the Law", in Oxford Studies in Philosophy of Law, vol. 1 (Lesley Green \& Brian Leiter, eds., Oxford, Oxford University Press, 2011), pp. 1-38, text also available at http://law.huji. ac.il/upload/Reason-Giving_and_the_Law.pdf.; see also David Enoch, “Giving Practical Reasons", Philosophers' Imprint, vol. 11(4) (March 2011), www.philosophersimprint.org/011004/.

As Rodriguez-Blanco points out, I have relied on Enoch's work in two of my recent works: "The Nature of Law and Reasons for Action", Problema. Anuario de Filosofía y Teoría del Derecho, No. 5, 2011, pp. 399-415, and "Law, Plans, and Reasons for Action" (review of Scott Shapiro, Legality), Ethics, vol. 122, pp. 444-448 (2012). 
BRIAN H. BIX

\section{EXPLAINING THE NORMATIVITY OF LAW}

Rodriguez-Blanco introduces her paper by informing us that "[t]he problem of how legal rules or directives give us reasons for action is the central problem of what has been called the "normativity of law" (man at p. 1, footnote omitted). It is important to be as precise about this as Rodriguez-Blanco is. In other discussions about "explaining" "the normativity of law," there often seems to be an assumption that all legal systems - or at least all "generally just" legal systems- give us reasons for action all the time. ${ }^{4}$

It is well known that the "normative nature of law" is central, in different ways, to many of the most important modern jurisprudential approaches to law, for example, those of H. L. A. Hart and Hans Kelsen. 5 Theorists have emphasized that one cannot properly understand law without focusing on the way that it purports to prescribe citizens' behavior. However, to have that as one's starting point that law (or "norms from generally just legal systems") always gives citizens reasons for action would be to beg a highly controversial question - the question of under what circumstances (and how frequently) legal systems and legal norms in fact give us reasons for action-. As Rodriguez-Blanco points out, there is always a danger in assuming what is still to be proven. While I do not agree with her accusation that Enoch developed his theory about reason-giving to fit his preferred theory about the nature of law (p. 3), I do not doubt that there are ample examples of theorists in this and related areas begging questions that should be open for discussion and analysis.

4 See, e.g., Jules L. Coleman \& Brian Leiter, "Legal Positivism", in Dennis Patterson (ed.), A Companion to Philosophy of Law and Legal Theory (2nd ed., Wiley-Blackwell, 2010), pp. 228-248.

5 See, e.g., H. L. A. Hart, The Concept of Law (2nd ed., Oxford, 1994); Hans Kelsen, Introduction to the Problems of Legal Theory (Bonnie Litschewski Paulson \& Stanley Paulson, trans., Oxford, 1992). 
Of course, speaking of "law's normativity" need not entail a view that legal systems (or generally just legal systems, or generally just legal norms) always give reasons for action, or even that they only presumptively do so. It would suffice that some legal systems - or just some legal norms- on some occasions give (some) individuals reasons for action. And one can take that starting point without falling into what Frederick Schauer considers to be a distinctive mistake of modern legal positivism: assuming that law is authoritative and that the Hartian "internal point of view"6 (the perspective of actors who believe that law gives them reasons for action) should be given priority in legal theory. ${ }^{7}$

As we shall see, though, even the assertion that law sometimes gives some people reasons for action requires clarification before one gets to explanation. For there are alternative "subjective" and "objective" ways of understanding the giving of reasons, as will be discussed in the next section. That some people might act (or refrain from acting) in a particular way, in this case, consistently with what legal norms prescribe, may call for a psychological explanation rather than a philosophical one just as one's wonder regarding why people treat the choices, actions, or comments of celebrities as reasons for action would be in the arena of psychology and sociology rather than philosophy). ${ }^{8}$ Our question is clearly more on the objective side of the question: why people justifiably should (at least on some occasions) treat legal rules as reasons for action; this question calls for a philosophical explanation.

Additionally, even if one grants or assumes that reason-giving by law is only "sporadic" (applying only to some legal norms and some people on some occasions), this rea-

6 See Hart, The Concept of Law, supra note 5, pp. 79-91.

7 See, e.g., Frederick Schauer, "Positivism Through Thick and Thin", in Brian Bix (ed.), Analyzing Law (Oxford, 1998), pp. 65-78, at pp. 70-78.

8 Rodriguez-Blanco does make a favorable, if passing, reference to "moral psychology" (p. 24); however, psychology, moral or otherwise, is not a topic on which I am qualified to comment. 
son-giving can still seem to be, in some senses, mysterious. How or in what way can the actions of officials (by voting for legislation, decision legal disputes in the courts, or promulgating administrative regulations) create for citizens reasons for action that they did not have before? The works of both Kelsen and Hart display puzzlement on this issue, a puzzlement increased by their belief that law should be understood as something conceptually separate from morality. Both Kelsen and Hart seem to find recourse in a not entirely persuasive) belief that law creates its own sort of normativity, much as a game does (chess reasons for action apply only to those who choose to play chess; could legal reasons be similarly autonomous?). ${ }^{9}$ However, Kelsen and Hart, and their views of legal normativity, are topics for another day; 10 we need to return to the debate between Rodriguez-Blanco and Enoch.

\section{THEORY (THEORIES) OF REASONS FOR ACTION}

In her article, Rodriguez-Blanco offers a useful overview of theories about reasons for action, dividing them into three categories: normativist approaches — to which she gives the most attention, in part because this is the category to which she assigns Enoch's work-; Humean approaches, which she seems to dismiss quickly; and approaches that connect reasons to the structure of intentions.

There are obvious difficulties in offering a general analysis of reasons for action, as it is hard to account simulta-

9 Cf. Andrei Marmor, Law in the Age of Pluralism (Oxford, 2007), pp. 153-181 ("How Law is Like Chess").

10 I also leave for others or for another day the important question of the precise way in which legal norms affect (or should affect) our reasons: do they merely produce reasons that are stronger than other (e.g. prudential) reasons, or do they work to exclude or pre-empt other reasons? See, e.g., Joseph Raz, Practical Reason and Norms (Princeton, 1990); Noam Gur, "Normative Weighing and Legal Guidance of Conduct", Canadian Journal of Law and Jurisprudence, vol. 25, pp. 359-391 (2012). 
neously for the objective aspect of reasons for action (what I actually have reason to do), the subjective aspect (what I think I have reason to do), and the persistence of guidance. As we are fallible reasoners, and certainly fallible moral reasoners, what we think we have reasons to do frequently diverges from what we actually have reasons to do. It may be that, in the end, no single theory can account for all aspects of reasons for action, just as it may be the case that no theory of the nature of law can account both for its quite different aspects - e.g., its role in practical reasoning and its status as a kind of social institution.

Rodriguez-Blanco does an excellent job of pointing out difficulties that most normativist approaches will have, including some that may be distinctive to Enoch's theory of reason-giving. One might only note that it would seem likely that alternative approaches (Rodriguez-Blanco hints at her preferred approach in this brief article, but does not fully display its outlines and justifications) might have the mirror problem - to be weak explaining just those aspects of reason-giving where normativist theories are strong. I leave to others more expert in this area to offer final judgments on whether a theory can adequately respond to all aspects of practical reasoning.

\section{LAW AND REASON-GIVING}

While the Introduction of Rodriguez-Blanco's paper begins by referring to the "problem of how legal rules or directives gives us reasons for action" and the "central question of legal normativity" (p. 1), law soon largely drops out of the discussion. ${ }^{11}$ She returns to the topic, in a tantalizing way, near the end of her critique of Enoch's approach:

11 Again, with the exception of Rodriguez-Blanco's accusation, in passing, that David Enoch had allowed his theory of reasons for action to be derived from or determined by his "own favoured theory of law" (p. 3). 
BRIAN H. BIX

It is trivially true to say that if we understand the phenomenon of reason-giving then we pave the way to better understanding how legal directives and rules give us reasons for actions... [W]e need to focus further on the phenomenology of legal directives, commands and rule-following in light of moral psychology and philosophy of action to achieve a sound theory of what legal normativity amounts to in terms of how legal directive and legal rules provide reasons for action (pp. 23-24).

There will be more on Rodriguez-Blanco's ideas about normativity later in this section; for now, I would like to return to the "law" aspect of the topic, if for no other or better reason than that I am more comfortable analyzing theories about the nature of law than I am analyzing theories about reasons and reasoning.

Those who argue that law gives -or at least that generally just legal systems or the legal norms of generally just legal systems give- prima facie reasons for action have a difficult task. They must show that (all or some category of) legal norms always give reasons to act in compliance. Of course, the argument does not have to be that such reasons are conclusive; it is sufficient that the legal norms give weight in favor of a particular action or forbearance, even if factors unrelated to the legal norm in question might create stronger reasons against that action or forbearance (as when one rightfully violates legal rules about maximum driving speeds to rush a seriously injured friend to the hospital).

David Enoch's ultimate position, echoing that of Joseph Raz, M. B. E. Smith, and many others, is that legal norms sometimes give people reasons for action, but the matter is contingent, depending on the norm, the subject-matter, and the actor. ${ }^{12}$ This reflects a presumptive individualism in moral decision-making: that presumptively each person

12 See Enoch, supra note 3, at 14-33; Joseph Raz, Ethics in the Public Domain (Oxford, 1994), pp. 325-338; M. B. E. Smith, "Is There a Prima Facie Obligation to Obey the Law?", Yale Law Journal, vol. 82, pp. 950-976 (1973). 
should decide how to act for herself, and case by case, unless and until a good reason is given to defer to others or to decide on a categorical basis.

Those who wish to argue that all the norms of (some) legal systems create reasons for action must offer an analysis that does not turn on the content of particular legal norms. ${ }^{13}$ The difficulty, as skeptics of such claims point out, is that with many (if not most) legal norms there are likely circumstances where non-compliance with the norm has little to no negative effect in the world - no harm to other people or to society generally, and no undermining of other people's respect for or support of the law- and in such circumstances it is hard to see why we would have a reason to comply.

How could one respond to this sort of critique? Perhaps to create a general or presumptive obligation to obey the law, one would need to avoid an instrumental approach to understanding the benefits of law - for if the focus is on the benefits that legal norms or the legal system as a whole are there to create, it is always open to the skeptic to argue that the morally autonomous agent should investigate, case by case, whether such benefits are in fact achieved, and, inevitably, there will be occasions when no benefits are in fact achieved by that actor's compliance. It would appear to be the case that to defeat the skeptic one would need an argument that law -as a system and in all of its (not extremely unjust) legal norms- has significant intrinsic value, and not just potential instrumental value. ${ }^{14}$

\footnotetext{
13 Even if one accepts with Gustav Radbruch (and some understandings of Aquinas) that extremely unjust norms lose their status as laws, see Gustav Radbruch, "Statutory Lawlessness and Supra-Statutory Law" (trans. Bonnie Litschewski Paulson \& Stanley L. Paulson), Oxford Journal of Legal Studies, vol. 26, pp. 1-11 (2006), that still leaves the problem of justifying the reason-giving power of all the remaining norms, regardless of their moral value, their significance, and their success in coordinating behavior.

14 See George Duke, "Finnis on the Authority of Law and the Common Good", Legal Theory (forthcoming) (making a similar argument, at greater
} 
Rodriguez-Blanco, in her many writings (both published ${ }^{15}$ and unpublished) ${ }^{16}$ seems to offer an approach along these lines, focusing on the "good-making characteristics of legal rules". ${ }^{17}$ Under this approach, the following of legal rules -the use of legal rules as guidance- is tied closely to the goods officials intend to achieve, both through the creation of a legal system, and through individual legal norms. Rodriguez-Blanco's argument has been that law is authoritative because law purports to be good, and endeavors to create this good (or these goods) in a special way (through the rule of law). ${ }^{18}$

One can see how the potential or intended good of the legal system as a whole, or of particular legal norms (or sets of legal norms —as in areas of law-), could (subjectively) guide behavior. We are attracted to the good in the law, and the good that law can achieve. We want to support it. Thus, we can explain why we do follow the law, or why we do obey particular legal rules. However, the objectivist question still comes: when are we morally obligated to follow the law?

length, in the context of offering a critique of John Finnis's defense of a moral obligation to obey the law).

15 Veronica Rodriguez-Blanco, “The Moral Puzzle of Legal Authority”, in Stefano Bertea \& George Pavlakos (eds.), New Essays on the Normativity of Law (Oxford: Hart Publishing, 2011), pp. 86-106; Veronica Rodriguez-Blanco, "Claims of Legal Authorities and 'Expressions of Intention': The Limits of Philosophy of Language", in Current Legal Issues (Michael Freeman \& Fiona Smith (eds.), forthcoming, Oxford University Press, 2013); see also Veronica Rodriguez-Blanco, "Social and Justified Legal Normativity: Unlocking the Mystery of the Relationship", Ratio Juris, vol. 25, pp. 409-433 (2012).

16 E.g., Veronica Rodriguez-Blanco, "Legal Rules in the Guise of the Good" (unpublished manuscript, 2010) (on file with author); Veronica Rodriguez-Blanco, Law Under the Guise of the Good (unpublished book manuscript, 2010) (on file with author).

17 E.g., Rodriguez-Blanco, "Legal Rules in the Guise of the Good", supra note 16 (man. at 20).

18 E.g., Rodriguez-Blanco, "The Moral Puzzle of Authority," supra note 15 , at $87 \& \mathrm{n}$. 5. She adds that Nazi law fails to be an authority because it is not an instance of authority as a good sort of thing. Íd. at 101. 
One can concede that governments that try to do good things, and do so through rule of law procedural standards, are themselves good: that we have reason to create them and support them while they are created. As already discussed, however, it is another matter to show that individual citizens have reasons to comply with individual legal norms. It is certainly true that for centuries it had been assumed that the conclusion that a government was legitimate or that a legal system was generally just would entail the further conclusion that citizens had at least a presumptive moral obligation to obey. However, modern theorists of the question of the moral obligation to obey the law no longer assume that one view entails the other; they generally hold that the moral obligation to obey requires an additional argument. ${ }^{19}$

Citizens would have a reason to comply if non-compliance would significantly harm a generally just legal system (in Aquinas's phrase, "create disorder or demoralization"), ${ }^{20}$ but that is rarely the case. With most instances of deciding whether to comply with a legal norm or not, no good reason has been offered against the default position: the practically reasonable person making a practically reasonable choice, case by case, regarding whether to comply with the law or not.

There are different sorts of arguments that might be offered, and which have been offered, to try to create a global (or global-presumptive) obligation to obey the law. Often these run along the lines of a Kantian-style argument that individuals should not pick and choose because of the bad consequences should everyone approach legal norms that way. ${ }^{21}$ Another approach is to argue that practically reasonable people, aware of their own biases and interests, would

19 See, e.g., Smith, supra note 12, Raz, supra note 12.

20 Thomas Aquinas, Summa Theologica, I-II, Qu. 96, art. 4, corpus; see also John Finnis, Aquinas (Oxford, 1998), pp. 273-274.

21 An argument along these lines can be found in A. M. Honore, Making Law Bind (Oxford, 1987), pp. 117-138. 
BRIAN H. BIX

defer to the legal system, because a legal system is a method of distributing burdens and benefits across different individuals and groups; for someone to pick and choose is unfairly to accept benefits without accepting the corresponding burdens (and to accept law where it agrees with their own views of what needs to be done, but not to accept it when it varies from those views, though knowing that the rules there follow other citizens' views about what needs to be done). ${ }^{22}$

These are significant arguments, not to be dismissed lightly. However, it seems that one might still respond that in the end one is left with the practically reasonable person who must make the moral judgment for herself: giving due deference based one one's own fallibility and bias (though also keeping in mind the fallibility and bias that can, and often does, afflict lawmakers), should one obey particular legal norms?23

\section{CONCLUSION}

Veronica Rodriguez-Blanco's article makes an important contribution to the literature on the best understanding of reason-giving and practical reasoning. However, it is not

22 Arguments along these lines can be found in John Finnis, "The Authority of Law in the Predicament of Contemporary Social Theory", Notre Dame Journal of Law Ethics \& Public Policy, vol. 1, pp. 115-137 (1984); John M. Finnis, "Law as Co-ordination", Ratio Juris, vol. 2, pp. 97-104 (1989).

23 Thomas Christiano has argued that at least for legal norms that are the product of democratic decision-making, a failure to obey the law constitutes a failure to give equal respect to fellow citizens. See, e.g., Thomas Christiano, "The Authority of Democracy", Journal of Political Philosophy, vol. 12, pp. 266-290 (2004); Thomas Christiano, “Democracy's Authority: Reply to Wall”, Journal of Political Philosophy, vol. 14, pp. 101-110 (2006). This argument is part of a large issue that cannot be adequately discussed here; for now suffice it to say that I do not find the argument persuasive. I touch on the topic in a review of Christopher J. Peters, A Matter of Dispute (Oxford, 2011), to appear in Law and Philosophy (forthcoming). 
clear that an approach to reasons for action reformed along the lines Rodriguez-Blanco suggests would change or clarify the ultimate question on which she focuses: the way in which legal systems in general or individual legal norms do (or do not) give citizens reasons for action. The question of whether we have a general (presumptive) moral obligation to act (or refrain from acting) as legal norms direct us depends to a significant degree on whether there are good arguments against an individualistic, case by case, approach to responding to such norms. 
DR (C) 2013, Universidad Nacional Autónoma de México,

Instituto de Investigaciones Jurídicas 